Bangladesh J. Sci. Res. 30(1\&2): 69-79, 2017 (December)

\title{
LONG TERM CARRYING OVER EFFECTS OF BASIC SLAG, SOIL AGGREGATE SIZE AND GROUNDWATER TREATMENTS FOR THE RECLAMATION OF ACID SULFATE SOILS
}

\author{
Monija Manjur*, Sonia Hossain and Md. Harunor Rashid Khan \\ Department of Soil, Water and Environment, University of Dhaka, \\ Dhaka-1000, Bangladesh
}

\begin{abstract}
A pot experiment was conducted to study the carrying over effects of soil aggregate size, groundwater level and basic slag treatments in acid sulfate soils of Badarkhali and Cheringaseries which were examined for the reclamation during 1998-2001. Initially the soils were very strongly acidic $(\mathrm{pH} 3.9$ for Badarkhali; 3.6 for Cheringa) and very strongly saline (ECe $23 \mathrm{mS} / \mathrm{cm}$ for Badarkhali) to moderately saline $(10.3 \mathrm{mS} / \mathrm{cm}$ for Cheringa). Application of these treatments exerted remarkable improvement in soil fertility and plant growth on these soils after 18 years of occasional cultivation. In 2016, $\mathrm{pH}$ at different treatments in these soils ranged from 6.2 to 7.4 for Badarkhali, 5.2 to 7.1 for Cheringa and ECe from 1.7 to $3.2 \mathrm{mS} / \mathrm{cm}$ for Badarkhali, 1.5 to 8.75 for Cheringa soils. At the same time in Badarkhali soil, organic matter content $(1.3-2.8 \%)$, total $\mathrm{N}$ $(0.02-0.11 \%)$, available $\mathrm{N}(2.69-18.29 \mathrm{mmol} / \mathrm{kg})$, available $\mathrm{P}(0.78-5.08 \mathrm{mmol} / \mathrm{kg})$ were determined and almost similar values of these parameters were recorded in Cheringa soil. Available S contents were found to decrease and ranged from $0.06-0.18$ $\mathrm{cmol} / \mathrm{kg}$ in Badarkhali and $0.08-0.21 \mathrm{cmol} / \mathrm{kg}$ in Cheringa soils. In spite of using basic slag, the concentrations of lead and cadmium in the studied soils were determined below (highest value of $\mathrm{Pb}$ was $2.07 \mathrm{mg} / \mathrm{kg}$ and $\mathrm{Cd} 1.8 \mathrm{mg} / \mathrm{kg}$ ) the normal contents $(\mathrm{Pb} 70$ $\mathrm{mg} / \mathrm{kg}$ and $\mathrm{Cd} 10 \mathrm{mg} / \mathrm{kg}$ ) in the agricultural soils.
\end{abstract}

Key words: Acid sulfate soils, Aggregate size, Basic slag, Carrying over effects,

Groundwater level

\section{Introduction}

Acid sulfate soils (ASSs) are one of the problem soils in the world, which release huge amounts of acid and toxically high concentrations of metals. It also affects the biological activity in the soils as well as in the associated environments. The ASSs generate $\mathrm{H}_{2} \mathrm{SO}_{4}$ that brings their $\mathrm{pH}$ from 6 or 7 to below 4, and sometimes to as low as 2 . An associated problem is the release of metals from the soil (e.g., oxidation-driven mobilization of at least $\mathrm{Co}, \mathrm{Cu}, \mathrm{Mn}$, Mo and $\mathrm{Ni}$ ) by dissolving metal sulfides and metal-bearing aluminosilicates and other minerals, and the subsequent transport in water courses (Fältmarsch et al. 2009). Acid sulfate soils affect more than 100 million hectares (M ha) of land worldwide of which about $0.7 \mathrm{M}$ ha occurs in the coastal areas of Bangladesh where crop production is very low; somewhere the lands are unproductive, though the lands have high agricultural potential (Khan et al. 2016).

\footnotetext{
*Author for correspondence: <monija.swed1011@gmail.com>.
} 
Basic slag is a byproduct of steel industry in Bangladesh and can be collected almost free of cost for reclaiming the acid sulfate soils (Khan et al. 2006). The Si contained in basic slag decreases Mn toxicity, enhances insect and disease resistance, and increases the water-use efficiency. To achieve the highest rate of oxidation and effective drainage of sulfidic materials in heavy-textured ASSs, the aggregate sizes of the soils should be reasonably smaller; so that release of exchangeable acidity/salinity and toxic elements from the soils, enhances and improves crop production (Khan et al. 2008).

After a long time (18 years) occasional cultivation practices, it is obvious to have some changes in soil properties. The main problem concerning the utilization of steel slag in agriculture is its heavy metal contents which might be unavailable due to increase in soil $\mathrm{pH}$ through suitable treatments. Presence of heavy metals and availability of acidic cations affect soil properties. So, assessing the long term effectiveness of basic slag application on soil will help to evaluate the suitability and sustainability of using basic slag as an amendment in acid sulfate soils. Accordingly, the objective of this study was to evaluate the soil fertility, heavy metal status, the potentiality and effectiveness of the treatments for the reclamation of study of acid sulfate soils.

\section{Materials and Methods}

The bulk soils were collected from Purbapukuria of Badarkhali Upazila and Sarisabari of Chakaria Upazila under Cox's Bazar district in Bangladesh. The study area is located between latitude $21^{\circ} 38^{\prime}$ to $21^{\circ} 55^{\prime} \mathrm{N}$ and longitude $91^{\circ} 55^{\prime}$ to $92^{\circ} 10^{\prime} \mathrm{E}$, during March, 1998 (Kabir 2004). Soil layers of 0 - $20 \mathrm{~cm}$ (1st layer), $20-40 \mathrm{~cm}$ (2nd layer) and $40-60 \mathrm{~cm}$ (3rd layer) of fallow land were sun dried and crushed to the aggregate sizes of $<20$ and $20-30 \mathrm{~mm}$. The experiments were set up in a completely randomized design and the treatment combination used is presented in Table 1.Ten $\mathrm{kg}$ of air-dried coarse sand (1-2 mm), which was previously treated with tap water followed by $1 \mathrm{M}$ $\mathrm{HCl}$, and distilled water washing and then placed at the bottom of each of the tanks. Thereafter, the soil layers were placed in the concrete tanks according to the field arrangement like top layer on the top, and bottom layer at the bottom part of the concrete tank (Fig. 1). The size of the concrete tank was $0.6 \mathrm{~m} \times 0.6 \mathrm{~m} \times 0.8 \mathrm{~m}$, that is the inside area of each tank was about $0.4 \mathrm{~m}^{2}$. The soils amounting to about 70, 30 and $30 \mathrm{~kg}$ from the $1 \mathrm{st}, 2 \mathrm{nd}$ and $3 \mathrm{rd}$ layers, respectively i.e. a total of $130 \mathrm{~kg}$ soils having aggregate sizes of $<20$ and $20-30 \mathrm{~mm}$ were placed in the concrete tanks on the basis of treatments. Some tanks were designed having the facilities to receive the influence of groundwater at a depth of $50 \mathrm{~cm}$ beneath the soil surface. The Badarkhali and Cheringa soils in each tank were leached for 10 days ( $10 \mathrm{~L}$ per day) by tap and rain waters in order toincrease $\mathrm{pH}$ and to decrease the ECe values. Each tank received basic slag at the rates of 10 and $20 \mathrm{t} / \mathrm{ha}$ in the surface soil $(0-15 \mathrm{~cm})$ as per treatments done during July, 1998 (Khan et al. 2007). These soils were kept in the mentioned concrete tanks for 18 years in the net house of the Department of Soil, Water and Environment, University of Dhaka under natural rainfall and temperature conditions and sometimes used for different crop responses. Soil samples were collected, ground and 
screened through a $2 \mathrm{~mm}$ sieve which were used for chemical and physico-chemical analyses of soil properties. The soils were analyzed for $\mathrm{pH}$ (1: 2.5 water, Jackson 1973), ECe (Richards 1954), organic carbon (Nelson and Sommers 1982), total N (micro-Kjeldhal method, Jackson 1973), available N (1.3 M KCl extraction, Jackson 1973), available P (Olsen et al. 1954) and available S (Sakai 1978). Phyto-available heavy metals like lead and cadmium extracted by DTPA (Lindsey and Norvel 1978) and determined by atomic absorption spectrometer. The level of significance of different treatments was determined using least significance difference (LSD) techniques using Minitab version 17. Before transplantation of rice, basal doses of fertilizers containing $\mathrm{N}, \mathrm{P}$ and $\mathrm{K}$ at the rates of 120,60 and $80 \mathrm{~kg} / \mathrm{ha}$ as urea, triple super phosphate (TSP) and muriate of potash (MoP) were applied. The full doses of TSP and MoP and half of the urea was applied before transplantation.

Table 1. Treatments and their combinations for the pot experiments have done in 1998 (Khan et al. 2007).

\begin{tabular}{|c|c|c|c|c|c|}
\hline \multirow[t]{2}{*}{ Soils } & \multicolumn{2}{|c|}{ Treatment } & \multirow{2}{*}{$\begin{array}{l}\text { Aggregate size } \\
\text { (A: } \mathrm{mm} \text { ) }\end{array}$} & \multirow{2}{*}{$\begin{array}{l}\text { Groundwater level } \\
(\text { Gw: } \mathrm{cm})\end{array}$} & \multirow{2}{*}{$\begin{array}{l}\text { Basic slag } \\
\text { (BS: t/ha) }\end{array}$} \\
\hline & No. & Denotation & & & \\
\hline \multirow{8}{*}{ 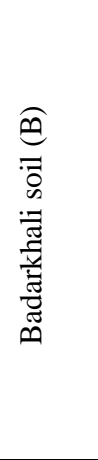 } & $\mathrm{T}_{1}$ & $\mathrm{BA}_{20} \mathrm{Gw}_{0} \mathrm{BS}_{10}$ & \multirow{4}{*}{$<20$} & \multirow{2}{*}{0} & 10 \\
\hline & $\mathrm{T}_{2}$ & $\mathrm{BA}_{20} \mathrm{Gw}_{0} \mathrm{BS}_{20}$ & & & 20 \\
\hline & $\mathrm{T}_{3}$ & $\mathrm{BA}_{20} \mathrm{Gw}_{50} \mathrm{BS}_{10}$ & & \multirow{2}{*}{50} & 10 \\
\hline & $\mathrm{T}_{4}$ & $\mathrm{BA}_{20} \mathrm{Gw}_{50} \mathrm{BS}_{20}$ & & & 20 \\
\hline & $\mathrm{T}_{5}$ & $\mathrm{BA}_{30} \mathrm{Gw}_{0} \mathrm{BS}_{10}$ & \multirow{4}{*}{$20-30$} & \multirow{2}{*}{0} & 10 \\
\hline & $\mathrm{T}_{6}$ & $\mathrm{BA}_{30} \mathrm{Gw}_{0} \mathrm{BS}_{20}$ & & & 20 \\
\hline & $\mathrm{T}_{7}$ & $\mathrm{BA}_{30} \mathrm{Gw}_{50} \mathrm{BS}_{10}$ & & \multirow{2}{*}{50} & 10 \\
\hline & $\mathrm{T}_{8}$ & $\mathrm{BA}_{30} \mathrm{Gw}_{50} \mathrm{BS}_{20}$ & & & 20 \\
\hline \multirow{8}{*}{ 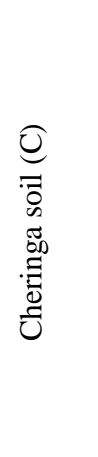 } & $\mathrm{T}_{9}$ & $\mathrm{CA}_{20} \mathrm{Gw}_{0} \mathrm{BS}_{10}$ & \multirow{4}{*}{$<20$} & \multirow{2}{*}{0} & 10 \\
\hline & $\mathrm{T}_{10}$ & $\mathrm{CA}_{20} \mathrm{Gw}_{0} \mathrm{BS}_{20}$ & & & 20 \\
\hline & $\mathrm{T}_{11}$ & $\mathrm{CA}_{20} \mathrm{Gw}_{50} \mathrm{BS}_{10}$ & & \multirow{2}{*}{50} & 10 \\
\hline & $\mathrm{T}_{12}$ & $\mathrm{CA}_{20} \mathrm{Gw}_{50} \mathrm{BS}_{20}$ & & & 20 \\
\hline & $\mathrm{T}_{13}$ & $\mathrm{CA}_{30} \mathrm{Gw}_{0} \mathrm{BS}_{10}$ & \multirow{4}{*}{$20-30$} & \multirow{2}{*}{0} & 10 \\
\hline & $\mathrm{T}_{14}$ & $\mathrm{CA}_{30} \mathrm{Gw}_{0} \mathrm{BS}_{20}$ & & & 20 \\
\hline & $\mathrm{T}_{15}$ & $\mathrm{CA}_{30} \mathrm{Gw}_{50} \mathrm{BS}_{10}$ & & \multirow{2}{*}{50} & 10 \\
\hline & $\mathrm{T}_{16}$ & $\mathrm{CA}_{30} \mathrm{Gw}_{50} \mathrm{BS}_{20}$ & & & 20 \\
\hline
\end{tabular}

Composition of basic slag (\%): $\mathrm{SiO}_{2}$ 12.8, Ca 20.8, $\mathrm{Mg}$ 9.8, $\mathrm{Fe} 11.3, \mathrm{Mn} 0.04, \mathrm{PO}_{4} 0.3$ and others 44.96, pH 9.6 (Khan et al. 2007). 


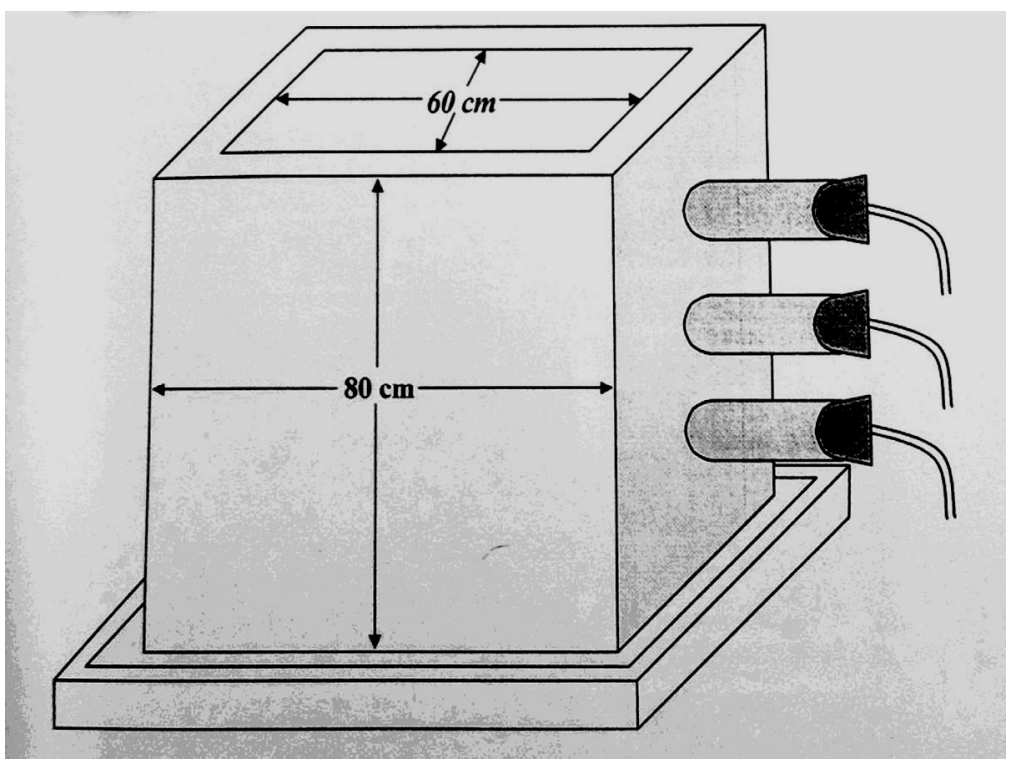

Fig. 1. Diagrammatic representation of a concrete tank used for the study.

\section{Results and Discussion}

Soil pH and ECe: In 1998, the initial pH was 3.9 for Badarkhali soil and 3.6 for Cheringa soil (Table 2). In 2001, which were found to be increased from 4.8 to 6.4 in Badarkhali and 4.6 to 5.4 in Cheringa soils. During March 2016, the soil pHs in different treatments ranged from 5.3 to 6.9 in Badarkhali and 4.7 to 6.4 in Cheringa soils. But after six months of the present study, the soil pHs in the different treatments were found to be increased from 6.2 to 7.4 in Badarkhali and 5.2 to 7.1 in Cheringa soils. Faster leaching of sulfidic materials as a result of smaller soil aggregate size treatment and quick formation of insoluble compounds like calcium carbonate helped to increase soil pHs. The rise of soil $\mathrm{pH}$ can also be caused by the application of basic slag through releasing exchangeable cations in the acid sulfate solution. The slow release of basic ions from the basic slag might hold the steady increase in pHs of soils (Shamim et al. 2009). During the study, the level of soil pHs were found higher than mentioned in both the soils, except for one treatment (Table 2). These increments can be caused due to cultivation practices. The overall $\mathrm{pH}$ values in both the soils were detected in a favorable $\mathrm{pH}$ range for crop growth though the Badarkhali soil was found to perform better than that of Cheringa soil.

The studied soils had originally (1998) high ECe values of $23 \mathrm{mS} / \mathrm{cm}$ for Badarkhali soil and $10.5 \mathrm{mS} / \mathrm{cm}$ for Cheringa soil, which were much higher than that of basic salinity level $(4 \mathrm{dS} / \mathrm{cm})$. The soils were recognized to have two-folds problems, such as, acidity and salinity. After 18 years (March 2016), the highest values of ECe were $5.20 \mathrm{mS} / \mathrm{c} \min \mathrm{T}_{8}\left(\mathrm{BA}_{30} \mathrm{GW}_{50} \mathrm{BS}_{20}\right)$ and $5.79 \mathrm{mS} / \mathrm{cm}$ $\operatorname{inT}_{12}\left(\mathrm{CA}_{20} \mathrm{GW}_{50} \mathrm{BS}_{20}\right)$ treatments, which were closer to the values reported in 2001 (Table 2). The reason behind increment might be due to drying out of soil and upward translocation of salts through capillary rise in subsoil. In September, 2016 most of the applied treatments in Badarkhali 
soil were found to decrease in ECe values. But applied treatments in Cheringa soil were found to increase the values in ECe (Table 2) due to cultivation practices. However, in comparison to the initial ECe values of both the soils, the values found during September, 2016 were in the range of slightly saline, which indicate that the soils were also reclaimed in relation to salinity.

Organic matter, total nitrogen and $\mathrm{C} / \mathrm{N}$ ratio: Soil organic matter is the reservoir of metabolic energy. A good agricultural soil should have around 2\% organic matter (Fertilizer Recommendation Guide 2012). In 1998, the organic matter contents were 3.1 and $4.0 \%$ for Badarkhali and Cheringa soils, respectively. In 2016, the ranges of organic matter contents were 1.3 to $2.8 \%$ in Badarkhali and 1.3 to $3.0 \%$ in Cheringa soils (Fig. 2). Though the organic matter decreased in both the soils due to cultivation practices, but still the contents of organic matter in the soils were reasonably enough for plant growth in relation to the soils of Bangladesh, where average organic matter content is $<1.0 \%$.

Table 2. Influences of selected treatments on pH and ECe during 1998 to 2016 in two acid sulfate soils $(0$ - $15 \mathrm{~cm})$.

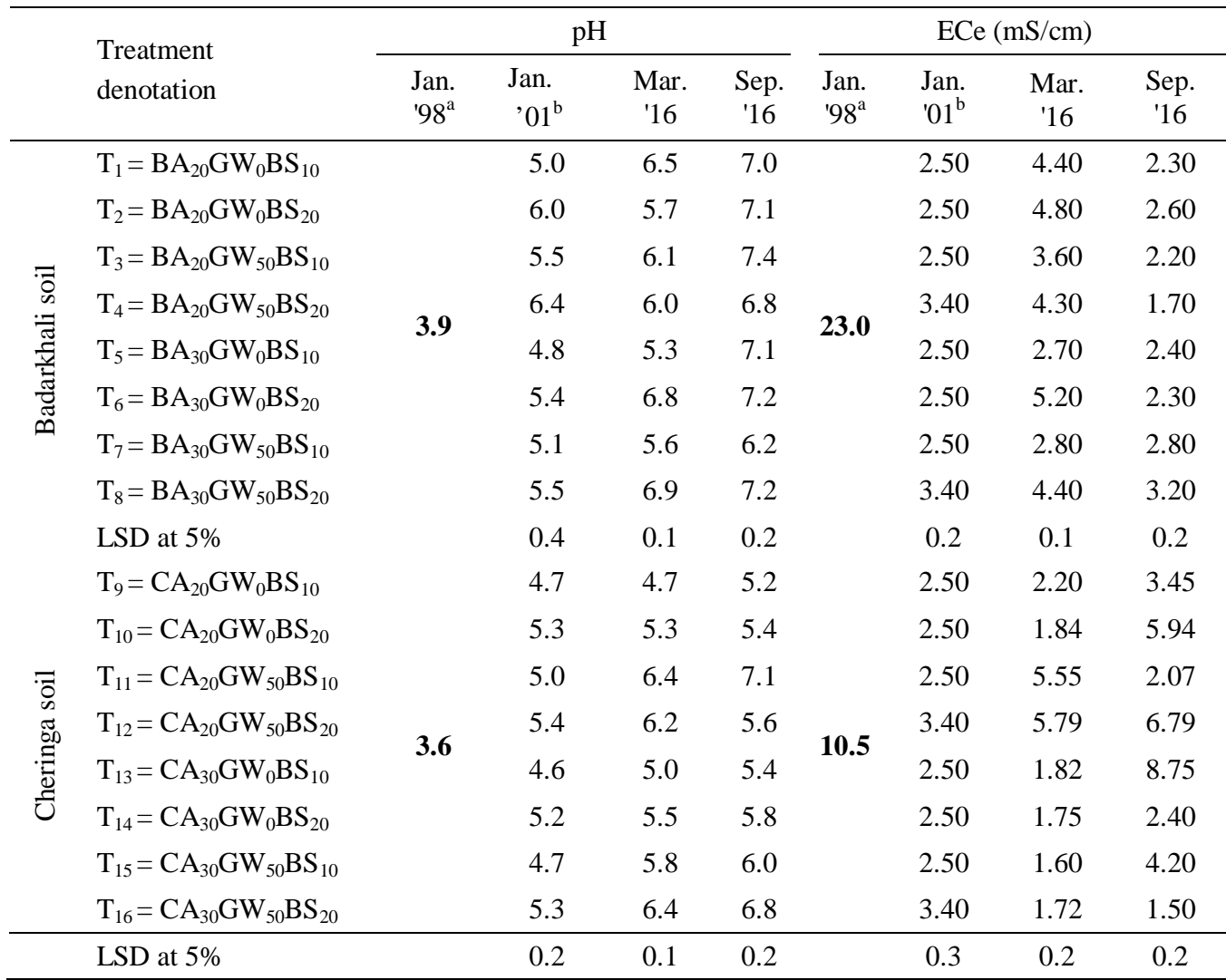

Khan and Blume (1998); Khan and Blume (2001). 
In 1998, the total nitrogen contents in both the soils were very low. After 18 years, these values of total nitrogen contents were found to have increased significantly ( $\mathrm{p} \leq 0.05$ : Fig. 3 ). These increments might be attributed to increase in soil $\mathrm{pH}$, enhancement in mineral fertilization, an accompanying increase in the availability of nutrients, and/or decrease of toxicity of some elements like $\mathrm{Al}$ and $\mathrm{Fe}$ (Khan et al. 1991).

Initially (1998), the $\mathrm{C} / \mathrm{N}$ ratio of the studied soil was 15 for Badarkhali soil and 16.5 for Cheringa soil. In March, 2016, C/N ratio ranged from 14.35 to 26.61 in Badarkhali soil andfrom 12.61 to 27.33 in Cheringa soil. In September, 2016, the $\mathrm{C} / \mathrm{N}$ ratio of Badarkhali soil ranged from 8.86 to 21.34 and from 10.90 to 18.81 in Cheringa soil (Fig. 4). These ranges insight us that the

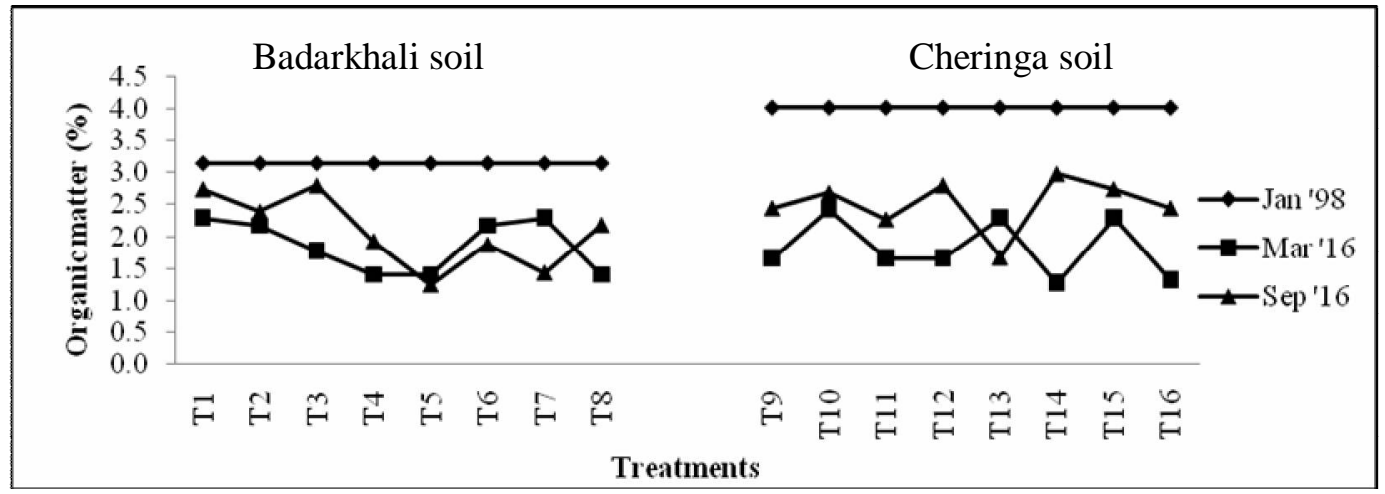

Fig. 2. Changes in organic matter content of Badarkhali and Cheringa soils during 1998 to 2016.

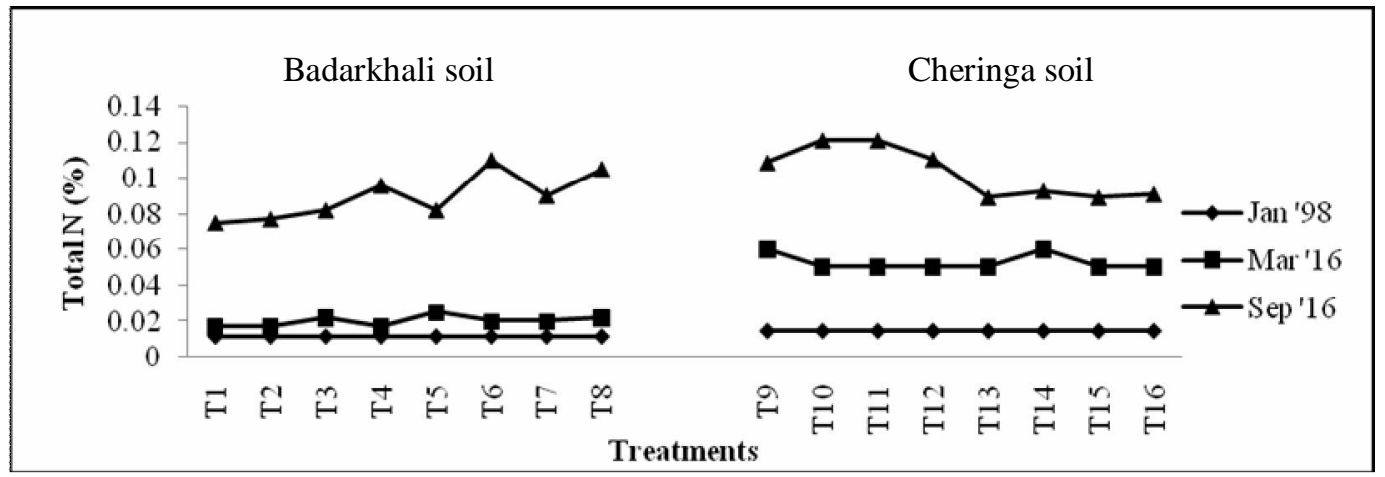

Fig. 3. Changes in total nitrogen of Badarkhali and Cheringa soils during 1998 to 2016.

changes in $\mathrm{C} / \mathrm{N}$ ratio gradually turned towards the optimum level, which might be due to the time required for the decomposition cycle to run its course depending on the quantity of organic matter added, the supply of inorganic $\mathrm{N}$, the resistance of the material to microbial attack, temperature and soil moisture level (Tisdale et al. 2003). 
Available nitrogen, phosphorus and sulfur: In 2016, the available N contents ranged from 2.69 to $18.29 \mathrm{mmol} / \mathrm{kg}$ in Badarkhali and 3.48 to $14.73 \mathrm{mmol} / \mathrm{kg}$ in Cheringa soil (Fig. 5). The contents of N were found to decrease in September, 2016 compared to that of 1998, which might be due to subsequent cultivation practices, crop removal and to reduction of sulfidic materials.

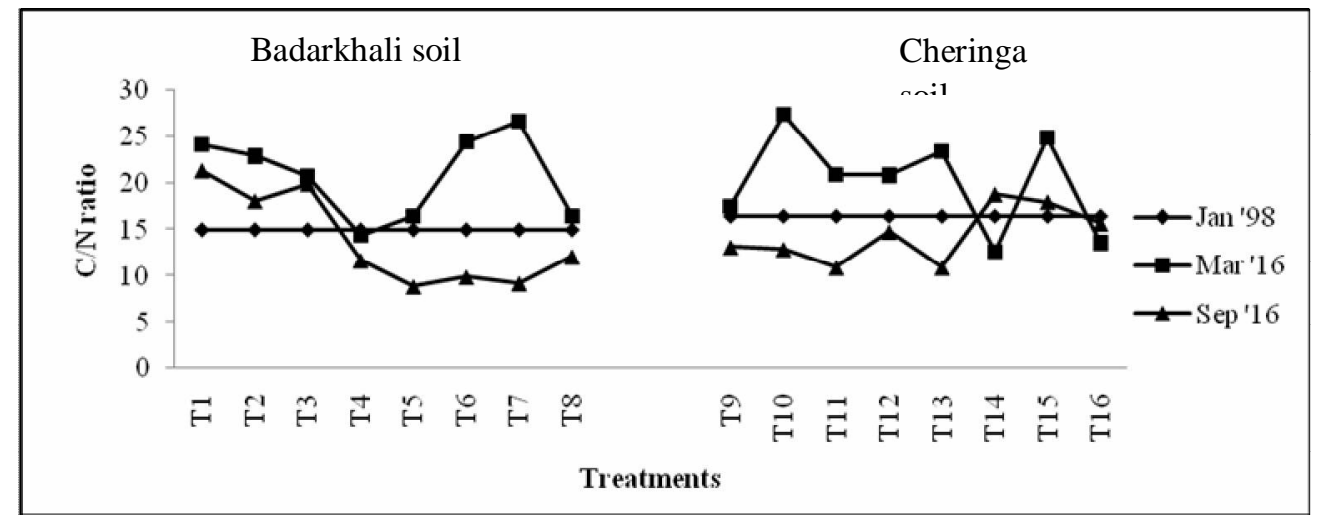

Fig. 4. Changes in C/N ratio of Badarkhali and Cheringa soils during 1998 to 2016.

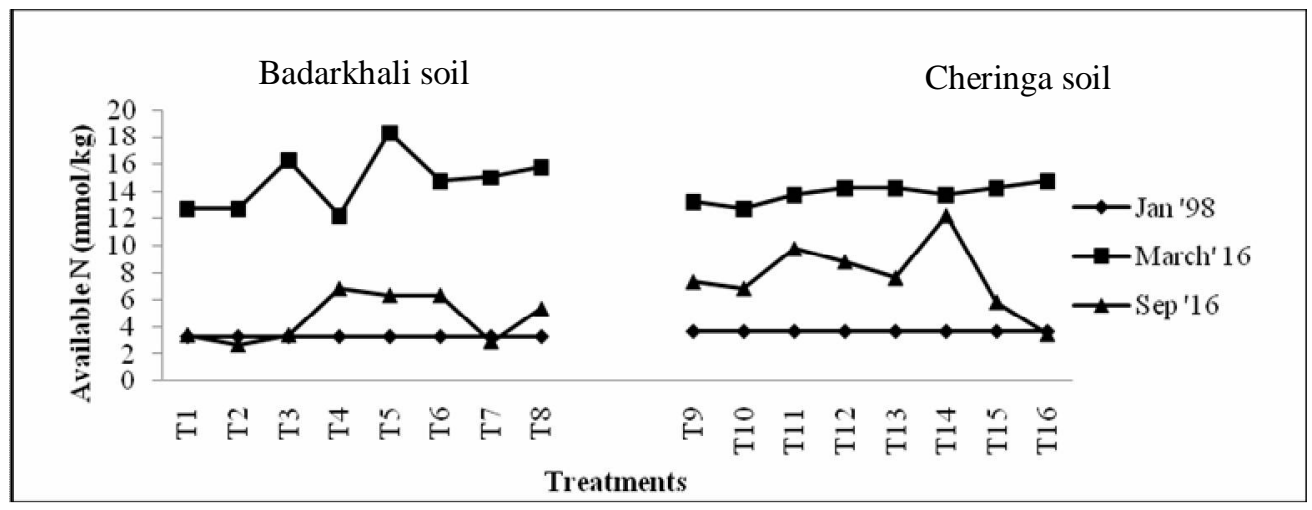

Fig. 5. Changes in available $\mathrm{N}$ of Badarkhali and Cheringa soils during 1998 to 2016.

Available P contents of these soils were low in 1998. In 2016, Badarkhali soil showed a significant increment in $\mathrm{P}$ contents than that of Cheringa soil. The $\mathrm{P}$ contents ranged from 0.78 to $5.08 \mathrm{mmol} / \mathrm{kg}$ in Badarkhali and 0.06 to $0.71 \mathrm{mmol} / \mathrm{kg}$ in Cheringa soil (Fig. 6). In September, the values of $\mathrm{P}$ were found to be increased, which might be due to the increase in soil $\mathrm{pH}$. Soils with the initial $\mathrm{pH}$ values between 6 and 7.5 are ideal for $\mathrm{P}$ availability, while $\mathrm{pH}$ values below 5.5, and between 7.5 and 8.5 limits $\mathrm{P}$ availability as a result of fixation by aluminum, iron, or calcium (USDA-NRCS 2014). The pH values of studied soils were around 7 for Badarkhali and 6 for Cheringa soil and the findings are in agreement with the above mentioned results. 
Initially (1998), the available sulfur contents in both the soils were very high. The sulfur contents decreased to about $97 \%$ in both Badarkhali and Cheringa soil (Fig. 7).

However, in both March and September of 2016, the S contents were determined significantly $(\mathrm{p} \leq 0.05)$ lower than those of their earlier values. This might be the effect of basic slag in reducing $\mathrm{H}_{2} \mathrm{~S}$ toxicity and reduction of acidity (Kabir 2004). Application of water to remove salinity and therefore greater downward movement of $\mathrm{SO}_{4}{ }^{2-}$ also happened. Moreover, as with $\mathrm{N}$, $\mathrm{S}$ might be converted into unavailable forms and thus, the $\mathrm{S}$ contents in the soils became reduced.

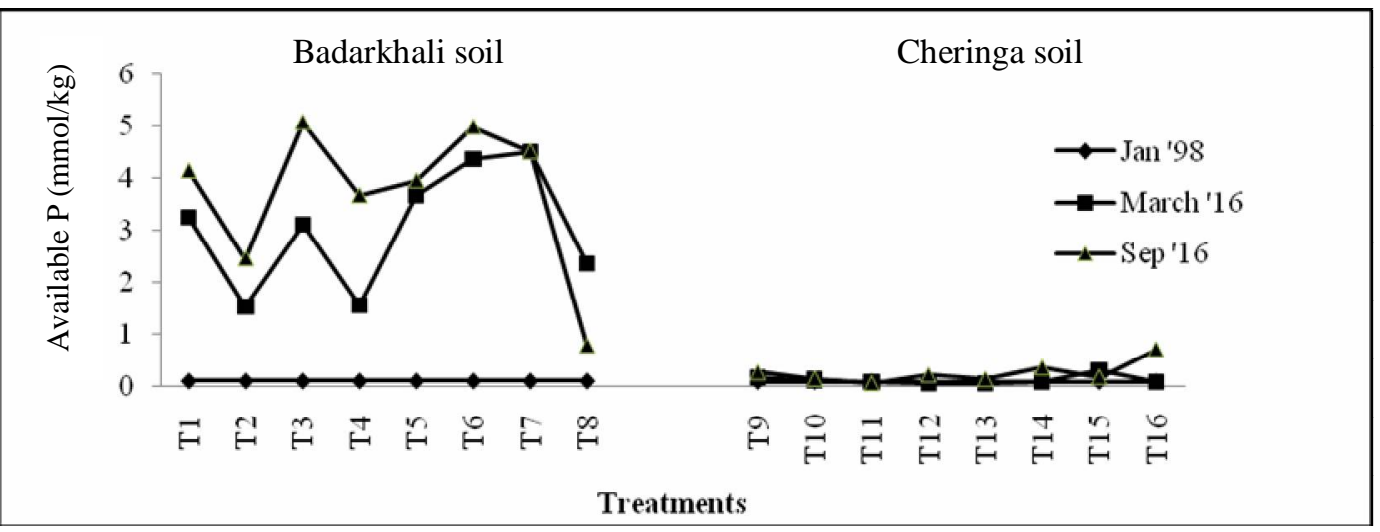

Fig. 6. Changes in available P of Badarkhali and Cheringa soils during 1998 to 2016.

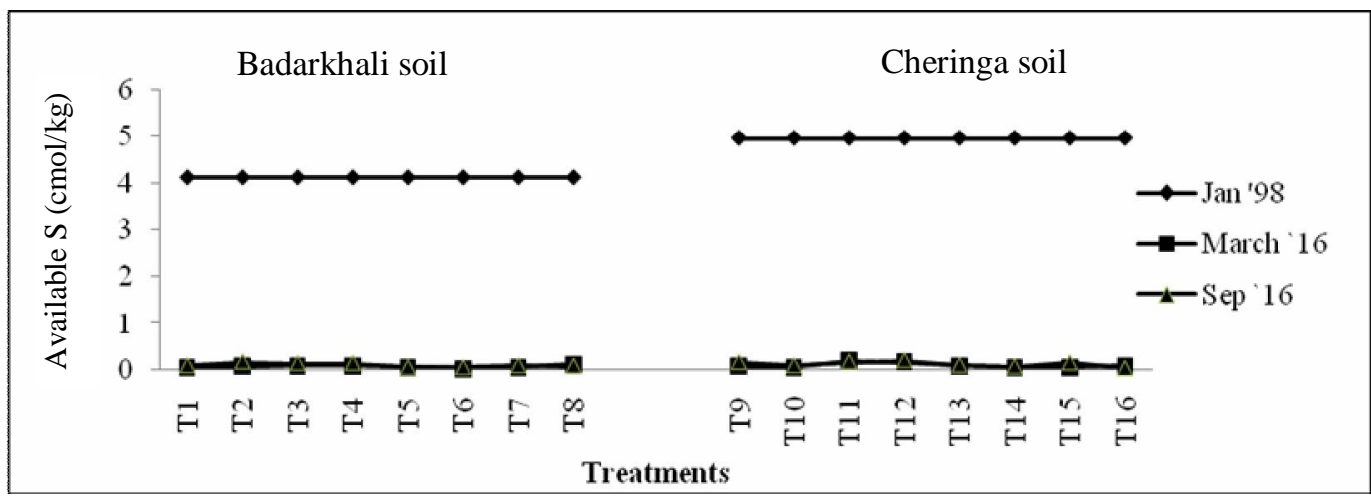

Fig. 7. Changes in available S of Badarkhali and Cheringa soils during 1998 to 2016.

Heavy metals: For the reclamation of acid sulfate soils in Bangladesh, the application of basic slag was started in the early nineties. From these results, Khan et al. (1996) reported that basic slag used for this study was free of toxic concentration of heavy metals. In March, 2016 the highest $\mathrm{Pb}$ concentration was $1.51 \mathrm{mg} / \mathrm{kgin}$ Badarkhali and $1.71 \mathrm{mg} / \mathrm{kg}$ in Cheringa soils. After 6 months cultivation practices, the highest concentration of $\mathrm{Pb}$ was $2.07 \mathrm{mg} / \mathrm{kg}$ for Badarkhali $\left(\mathrm{T}_{6}\right)$ and $2.07 \mathrm{mg} / \mathrm{kg}$ for Cheringa $\left(\mathrm{T}_{16}\right)$ soils (Table 3 ). 
The $\mathrm{Pb}$ concentration was very low compared to the value $70 \mathrm{mg} / \mathrm{kg}$ for good soil quality (Ezigbo 2011). In March 2016, the highest concentration of Cd was $1.8 \mathrm{mg} / \mathrm{kg}$ in Badarkhali and $0.09 \mathrm{mg} / \mathrm{kg}$ in Cheringa soils. But after 6 months of cultivation practices, the Cd concentration was $0.1 \mathrm{mg} / \mathrm{kg}$ for Badarkhali and $0.08 \mathrm{mg} / \mathrm{kg}$ for Cheringa soils in September, 2016. The $\mathrm{Cd}$ concentration was very low from the given value $10 \mathrm{mg} / \mathrm{kg}$ (Ezigbo 2011) for good soil quality. Usually decreasing $\mathrm{pH}$, increasing salinity level and $\mathrm{Zn}$ deficiencies are the main soil factors for Cd uptake by plants (Chaney and Hornick 1978). After 18 years of occasional cultivation practices, the present experiment showed that the soils had high $\mathrm{pH}$ and low salinity, which establishes that the application of basic slag reclaimed the soil properly and the availability of heavy metals in the studied soils were very below the harmful level, suggesting that the use of studied basic slag is safe in relation to heavy metal contents in the soils.

Table 3. Heavy metal contents in Badarkhali and Cheringa soils in 2016 as influenced by selected treatments.

\begin{tabular}{|c|c|c|c|c|c|}
\hline & \multirow{2}{*}{ Treatment denotation } & \multicolumn{2}{|c|}{ Available $\mathrm{Pb}(\mathrm{mg} / \mathrm{kg})$} & \multicolumn{2}{|c|}{ Available $\mathrm{Cd}(\mathrm{mg} / \mathrm{kg})$} \\
\hline & & Mar. '16 & Sep. '16 & Mar. '16 & Sep. '16 \\
\hline \multirow{7}{*}{ 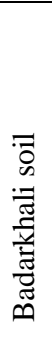 } & $\mathrm{T}_{1}=\mathrm{BA}_{20} \mathrm{GW}_{0} \mathrm{BS}_{10}$ & 0.91 & 1.13 & 0.03 & 0.06 \\
\hline & $\mathrm{T}_{2}=\mathrm{BA}_{20} \mathrm{GW}_{0} \mathrm{BS}_{20}$ & 1.09 & 1.37 & 0.10 & 0.10 \\
\hline & $\mathrm{T}_{3}=\mathrm{BA}_{20} \mathrm{GW}_{50} \mathrm{BS}_{10}$ & 0.91 & 1.41 & 0.03 & 0.04 \\
\hline & $\mathrm{T}_{4}=\mathrm{BA}_{20} \mathrm{GW}_{50} \mathrm{BS}_{20}$ & 0.77 & 0.93 & 0.03 & 0.05 \\
\hline & $\mathrm{T}_{5}=\mathrm{BA}_{30} \mathrm{GW}_{0} \mathrm{BS}_{10}$ & 0.65 & 0.87 & 0.04 & 0.07 \\
\hline & $\mathrm{T}_{6}=\mathrm{BA}_{30} \mathrm{GW}_{0} \mathrm{BS}_{20}$ & 1.51 & 2.07 & 1.80 & 0.10 \\
\hline & $\mathrm{T}_{7}=\mathrm{BA}_{30} \mathrm{GW}_{50} \mathrm{BS}_{10}$ & 0.53 & 0.85 & 0.02 & 0.04 \\
\hline \multirow{11}{*}{ 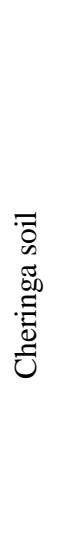 } & $\mathrm{T}_{8}=\mathrm{BA}_{30} \mathrm{GW}_{50} \mathrm{BS}_{20}$ & 0.85 & 1.07 & 0.07 & 0.10 \\
\hline & LSD at $5 \%$ & 0.02 & 0.01 & 0.01 & 0.01 \\
\hline & $\mathrm{T}_{9}=\mathrm{CA}_{20} \mathrm{GW}_{0} \mathrm{BS}_{10}$ & 0.07 & 0.23 & 0.01 & 0.02 \\
\hline & $\mathrm{T}_{10}=\mathrm{CA}_{20} \mathrm{GW}_{0} \mathrm{BS}_{20}$ & 1.13 & 1.05 & 0.03 & 0.05 \\
\hline & $\mathrm{T}_{11}=\mathrm{CA}_{20} \mathrm{GW}_{50} \mathrm{BS}_{10}$ & 0.97 & 1.17 & 0.02 & 0.03 \\
\hline & $\mathrm{T}_{12}=\mathrm{CA}_{20} \mathrm{GW}_{50} \mathrm{BS}_{20}$ & 1.71 & 0.73 & 0.05 & 0.04 \\
\hline & $\mathrm{T}_{13}=\mathrm{CA}_{30} \mathrm{GW}_{0} \mathrm{BS}_{10}$ & 0.51 & 0.49 & 0.03 & 0.03 \\
\hline & $\mathrm{T}_{14}=\mathrm{CA}_{30} \mathrm{GW}_{0} \mathrm{BS}_{20}$ & 0.81 & 0.93 & 0.05 & 0.05 \\
\hline & $\mathrm{T}_{15}=\mathrm{CA}_{30} \mathrm{GW}_{50} \mathrm{BS}_{10}$ & 1.09 & 0.97 & 0.03 & 0.02 \\
\hline & $\mathrm{T}_{16}=\mathrm{CA}_{30} \mathrm{GW}_{50} \mathrm{BS}_{20}$ & 1.47 & 2.07 & 0.09 & 0.08 \\
\hline & LSD at $5 \%$ & 0.01 & 0.01 & 0.01 & 0.01 \\
\hline
\end{tabular}

\section{Conclusion}

The exploration from these 18 years of study reveals that extremely acidic soils can be useful for sustainable crop production through the present reclamation measures. The application of basic slag, soil aggregate size and groundwater level management reclaimed the Badarkhali and 
Cheringa acid sulfate soils successfully. The present results, such as, increased soil $\mathrm{pH}$, decreased $\mathrm{S}$ contents to optimum level and remarkably reduced heavy metal status lasting for a long time (18 years) also demonstrated that the reclamation of these soils are sustainable. Though, Badarkhali soil performed better because of its initial low acidic condition. Crop grown during 18 years of occasional cultivation practices reported satisfactory yields obtained like normal soils. The significant achievements of these reclamation techniques are the application of basic slag, which is free of toxic heavy metals, cheap and available as an industrial byproduct and other treatments are physical and have no scope of negative impacts on these soils.

\section{References}

Chaney, R.L. and S.B. Hornick. 1978. Accumulation and effects of cadmium on crops. In: Cadmium. Proc. 1st Int. Cd Conf. San Farncisco. Metal Bulletin Ltd, London. pp. 77.

Ezigbo, V.O. 2011. Determination of the trace metal concentrations in the soils of Nnewi north local government area. J. Basic Phys. Res. 2(1): 82-85.

Fältmarsch, R.,P. Österholm, M. Greger and M. Åström. 2009. Metal concentrations in oats (Avena sativa L.) grown on acid sulphate soils. Agri. and Food Sci. 18: 45-56.

FRG (Fertilizer Recommendation Guide). 2012. Bangladesh Agricultural Research Council, Dhaka.

Jackson, M.L.1973. Soil Chemical Analysis. Prentice Hall of India Pvt. Ltd. New Delhi. pp. 215-224.

Kabir, S.M. 2004. Acid sulfate soil ecosystems and their sustainable management, Unpublished Ph.D. Thesis, Dept. of Soil, Water and Environment, University of Dhaka, Dhaka 1000, Bangladesh.

Khan, H.R., S. Rahman, M.S. Hussain and T. Adachi. 1991. Effect of various liming materials and leaching on the uptake of nutrients by rice in two acid sulfate soils. Int. J. Trop. Agri. 9(3):215-224.

Khan, H.R. and H-P. Blume. 1998. Studies on Element Dynamics and Processes in Different Acidity Levels of Acid Sulfate Soil/Drainage Water Ecosystems and Their Sustainable Management. First Technical Report (Ref: 1/73 802, dated 03-08-98) submitted to the Volkswagen Foundation, FR-Germany.

Khan, H.R. and H-P. Blume. 2001. Studies on element dynamics and processes in different acidity levels of acid sulfate soil/drainage water ecosystems and their sustainable management. Third technical report (Ref: 1/73 802, dated 03-08-98) submitted to the Volkswagen Foundation, FR-Germany.

Khan, H.R., M.M.A. Bhuiyan, S.M. Kabir, Y. Oki and T. Adachi. 2006. Effects of selected treatments on the production of rice in acid sulfate soils in a simulation study. Jpn. J. Trop. Agr. 50(3): 109-115.

Khan, H.R., M.M.A. Bhuiyan, S.M. Kabir, H-P. Blume, Y. Oki and T. Adachi. 2007. Consequences of basic slag on soil $\mathrm{pH}$, calcium and magnesium status in acid sulfate soils under various water contents. J. Biol. Soc. Sci. 7: 896-903.

Khan, H.R., M.M.A. Bhuiyan, S.M. Kabir and H-P. Blume. 2008. Effects of basic slag, aggregate size and groundwater treatments on the production of Chili in acid sulfate soils in a simulation study. $J$. of the Faculty of Env. Sci. and Tech., Okayama University. 13:103-10.

Khan, H.R., S.M. Kabir and M.M.A. Bhuiyan. 2016. Effects of selected treatments and techniques for the reclamation and improvement of Cheringa acid sulfate soil under rice production in the coastal plain of Cox's Bazar. J. Asiat. Soc. Bangladesh, Sci. 42(1): 29-40.

Khan, H.R., S. Rahman, M.S. Hussain and H-P. Blume. 1996. Response of rice to basic slag, lime and leaching in two saline acid sulfate soils in pot experiments. Z. Pflanzenernahr. Bodenk. Weinheim, Germany 159: 549-555. 
Lindsay, W.L. and W.A. Norvell. 1978. Development of a DTPA soil test for zinc, iron, manganese and copper. J. Soil Sci. Soc. America 42: 421-428.

Nelson, D.W. and L.E. Sommers. 1982. Total carbon, organic carbon and organic matter. In: Methods of Soil Analysis, Part 2. Am. Soc. of Agron., Madison. pp. 539-579.

Olsen, S.R., C.V.Cale, F.S. Watanabe and L.A. Dean. 1954. Estimation of available phosphorus in soils by extraction with sodium bicarbonate.Washington, USA.

Richards, L.A. 1954. Diagnosis and improvement of saline and alkali soils. In: USDA Handbook, No. 60, US Government Printing Office, Washington, USA, pp. 84-156.

Sakai, H. 1978. Some analytical results of sulfur deficient plants, soil and water. Workshop on sulfur nutrition in rice. $41: 35-59$.

Shamim, A.H., H.R. Khan and T. Akae 2009. Effects of incubation times and moisture regimes on pH values and exchangeable cations in acid sulfate soils as influenced by application rates of basic slag. Paddy Water Environ. 7: 95-103.

Tisdale, S.L., W.L. Nelson, J.D. Beaton and J.L. Havlin. 2003. Soil fertility and fertilizers. 5th Ed. PrenticeHall, Inc. New Jersey, US.

USDA-NRCS (United States Department of Agriculture - Natural Resources Conservation Service). 2014. Soil phosphorus. Soil health- Guide for educators.

(Manuscript received on 21 September, 2017; revised on 28 February, 2018) 